\title{
Horticultural Performance of Native White Chilean Strawberry in San Pedro, Metropolitan Region of Chile
}

\author{
Tricia Contreras \\ Facultad de Ciencias Agrarias, Universidad de Talca, Casilla 747, Talca, Chile
}

Jorge B. Retamales

Facultad de Ciencias Agrarias and Centro de Investigación en Biotecnología Silvoagrícola, Universidad de Talca, Casilla 747, Talca, Chile

During the 2001-02 growing season, a field experiment was planted in the winter in the county of San Pedro, Metropolitan Region $\left(33^{\circ}\right.$ 58 'S $\left.71^{\circ} 29^{\prime} \mathrm{W}\right)$, where $40 \%$ of the commercial strawberry (Fragaria $\times$ ananassa $)$ production is

concentrated in Chile. The aim of the experiment was to evaluate the horticultural performance of native white Chilean strawberry (F. chiloensis) to establish the possibility of introducing this species as a new crop for small land owners.

Table 1. Dry matter per plant (DMPP) and proportions (\%) partitioned into leaves, crowns, roots, flowers/ fruit, and stolons in five Fragaria genotypes [three cultivars of $F$. $\times$ ananassa (Duch.) and two accessions of F. chiloensis (L.) Duch.].

\begin{tabular}{|c|c|c|c|c|c|c|}
\hline \multirow[b]{2}{*}{ Germplasm } & \multirow{2}{*}{$\begin{array}{c}\text { DMPPz }^{z} \\
(\mathrm{~g})\end{array}$} & \multicolumn{5}{|c|}{ Proportion of dry matter $(\%)^{y}$} \\
\hline & & Leaves & Crowns & Roots & Flowers/fruit & Stolons \\
\hline \multicolumn{7}{|l|}{$\bar{F} \times$ ananassa } \\
\hline Camarosa & $56.7 \mathrm{a}^{\mathrm{z}}$ & 69.1 & 11.9 & 14.8 & $4.2 \mathrm{~b}$ & $0 \mathrm{c}$ \\
\hline Seascape & $35.5 \mathrm{~b}$ & 68.2 & 13.1 & 12.9 & $5.8 \mathrm{ab}$ & $0 \mathrm{c}$ \\
\hline Selva & $26.4 \mathrm{~b}$ & 63.0 & 15.9 & 13.1 & $8.0 \mathrm{a}$ & $0 \mathrm{c}$ \\
\hline \multicolumn{7}{|l|}{ F. chiloensis } \\
\hline 97PUR 1-A & $20.5 \mathrm{~b}$ & 65.8 & 15.1 & 12.9 & $0.4 \mathrm{c}$ & $5.8 \mathrm{~b}$ \\
\hline 94 BAU 1-A & $32.6 \mathrm{~b}$ & 62.7 & 12.8 & 13.0 & $0.6 \mathrm{c}$ & $10.9 \mathrm{a}$ \\
\hline Significance & $*$ & NS & NS & NS & $* *$ & $* *$ \\
\hline
\end{tabular}

${ }^{2}$ Values are average of four replications per treatment.

${ }^{y}$ Analysis based on data transformed through the arcsin V (\%) function.

${ }^{2}$ Averages followed by different letters in a column differ statistically by Duncan's test.

${ }_{\mathrm{NS}, *, * *}^{*}$ Nonsignificant or significant at $p \leq 0.05$ or 0.01 , respectively.

\section{Materials and Methods}

Three widely grown commercial strawberry varieties ('Camarosa', 'Seascape', and 'Selva')

Table 2. Fruit yield per plant (fresh weight in g) and number of crowns per plant in five Fragaria genotypes [three cultivars of $F$. ×ananassa (Duch.) and two accessions of $F$. chiloensis (L.) Duch.]. Values are average of four replications per treatment.

\begin{tabular}{lcc}
\hline Germplasm & $\begin{array}{c}\text { Yield/plant } \\
(\mathrm{g})\end{array}$ & $\begin{array}{c}\text { Crowns/ } \\
\text { plant }\end{array}$ \\
\hline F. $\times$ ananassa & & \\
Camarosa & $9.2 \mathrm{~b}^{2}$ & $5.0 \mathrm{a}$ \\
Seascape & $9.9 \mathrm{ab}$ & $3.8 \mathrm{ab}$ \\
Selva & $12.5 \mathrm{a}$ & $3.5 \mathrm{ab}$ \\
F. chiloensis & & \\
97PUR1-A & $0.8 \mathrm{c}$ & $2.3 \mathrm{bc}$ \\
94BAU1-A & $2.0 \mathrm{c}$ & $1.8 \mathrm{c}$ \\
Significance & $* *$ & $* *$ \\
\hline
\end{tabular}

${ }^{2}$ Averages followed by different letters in a column differ statistically by Duncan's test.

${ }^{* *}$ Significant at $p \leq 0.01$.

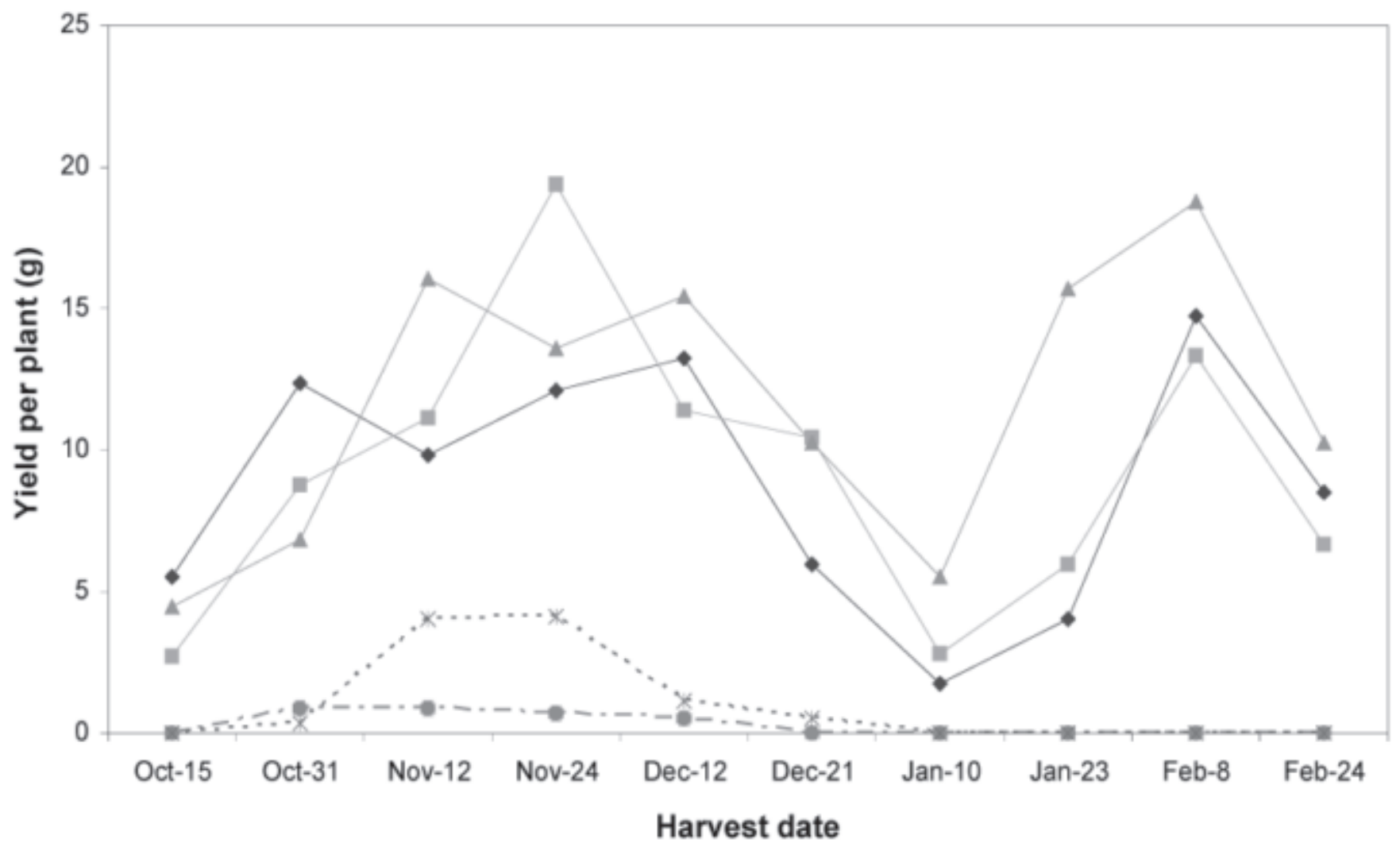

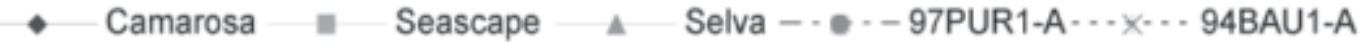

Fig. 1. Seasonal fruit production per plant in five genotypes of Fragaria [three $F$. $\times$ ananassa cultivars ('Camarosa', 'Seascape', and 'Selva') and two $F$. chiloensis accessions (97 PUR1A and 94 BAU 1A)]. 
and two accessions of $F$. chiloensis grown by small farmers in southern Chile (97PUR-1A and 94BAU-1A; Lavín and Maureira, 2000), were evaluated for growth, fruit quality, carbohydrate partitioning, and fruit production throughout the season. Ten plants in each of four replications were set in the field in May 2001 on 30-cm-high and $80-\mathrm{cm}$-wide beds at $40 \mathrm{~cm}$ distance among plants. A plastic mulch $(80 \mu \mathrm{m}$ in thickness; white on top, black on the bottom) was used to preclude weeds. Plants were drip irrigated according to needs established through a Class A evaporimeter. Standard horticultural practices used for growing commercial strawberries in Chile were employed throughout the season (Villagrán, 2001). No major pest or diseases were detected. Fruit were collected every 3 to $5 \mathrm{~d}$, from six plants in the central sector of each replication. Stolons were removed throughout the season within one week of their emergence. In each replication, five plants were removed from the field in May 2002, separated by plant part and the dry weight of each group was determined after drying in a forced draught oven at $72{ }^{\circ} \mathrm{C}$ until constant weight.

\section{Results and Discussion}

Even though clones of $F$. chiloensis have been reported as having higher photosynthetic rates than $F$. $\times$ ananassa (Cameron and Hartley, 1990), in our experiment, the Camarosa variety $(F . \times$ ananassa $)$ had the highest dry matter production and there were no differences among other Fragaria genotypes. These results might be explained by the effect of fruit load on total carbohydrate production, since research on F. ×ananassa (Choma et al., 1982; Lenz, 1974) has shown that the presence of fruit induces higher photosynthetic rates. The $F$. $\times$ ananassa cultivars assigned a significantly higher proportion of carbohydrates to flowers and fruits while most carbohydrates in $F$. chiloensis were partitioned towards the stolons (Table 1); this might be an ecological strategy of $F$. chiloensis to occupy the available space (Lavín and Maureira, 2000). Stolon removal in $F$. $\times$ ananassa with propensity for runnering has been shown to significantly increase early yields (Albregts and Howard, 1986). Fruit and crown production, as well as fruit size were significantly higher for $F$. $\times$ ananassa varieties (Table 2); Hancock (1999) has mentioned that fruiting restricts dry matter accumulation in other organs. Soluble solids levels were statistically similar for all Fragaria genotypes (from 9.3 to $10.2^{\circ} \mathrm{Brix}$; data not presented). $F$. $\times$ ananassa cultivars had a fruit production season of about 6 months as compared to 6 to 7 weeks in F. chiloensis genotypes. Commercial strawberry cultivars had two fruit production peaks, while $F$. chiloensis accessions had only one (Fig. 1).

\section{Literature Cited}

Albregts, E.E. and C.M. Howard. 1986. Effect of runner removal on strawberry fruiting response. HortScience 21:97-98

Cameron, J.S. and C.A. Hartley. 1990. Gas exchange characteristics of Fragaria chiloensis genotypes. HortScience 21:1225-1226

Choma, M.A., J.L. Garner, R.P. Marini, and J.R. Barden. 1982. Effect of fruiting on net photosynthesis and dark respiration of 'Hecker' strawberries. HortScience 17:212-213

Hancock, J.F. 1999. Strawberries. CAB Intl. Publ., New York.

Lavín, A. and M. Maureira. 2000. La frutilla chilena de fruto blanco. Instituto de Investigaciones Agropecuarias. Boletín INIA 39:34.

Lenz, F. 1974. Fruit effects on the formation and distribution of photosynthetic assimilates, $\mathrm{p}$. 155-166. In: R. Antoszewski, L. Harrison, and J. Nowosielski (eds.). Proc. XIXth Intl. Hort. Congr.

Villagrán, V. 2001. Frutilla, p. 993-1006. In: S. Román (ed.). Agenda del Salitre Soquimich. Undécima edición. Sociedad Química y Minera de Chile, Santiago. 